Volume 2, Number 2, 2016

\title{
Identification of Controlled Plant and Development of Its Model by Means of PLC
}

\author{
Roman Fedoryshyn", Sviatoslav Klos, Volodymyr Savytskyi, Oleh Masniak \\ Lviv Polytechnic National University, 12 Stepan Bandera St., Lviv, 79013, Ukraine
}

Received: November 2, 2016. Revised: December 21, 2016. Accepted: December 26, 2016.

(c) 2016 The Authors. Published by Lviv Polytechnic National University.

\begin{abstract}
The results of experimental and theoretical investigation of dynamic and static characteristics of a thermal object (electric oven) as a controlled plant are presented in the paper. The up-to-date microprocessor instruments were applied during the investigation. The experimental study of the plant was made by obtaining the step response curves for the controlling action channel and for the disturbance channel. Fifteen step response curves were recorded during the study. These curves were applied for development of the mathematical model of the plant in the form of static characteristics equations, transfer functions and differential equations. The structure of the model was chosen. The numerical values of the model parameters were calculated. The adequacy of the model was verified. The relative errors of the calculated values of the static characteristics points do not exceed $5 \%$. The maximum reduced error of the simulated step response curve in comparison to the experimental curve is $7 \%$ for the proposed combined method of defining the time constants. The developed model was implemented in a programmable logic controller in order to provide the possibility of studying the automatic control loop with various control laws.
\end{abstract}

Keywords: controlled plant; step response curve; transient process; mathematical model; electric oven.

\section{Introduction}

Development of a mathematical model is an important step on the way of a controlled plant investigation. The model provides the possibility of studying the behavior of the plant at disturbances of various types and of various values through modeling without making the additional experiments. The mathematical model enables also the structure of an automatic controller to be designed and the tuning parameters of the controller to be calculated in order to provide the needed quality of the transient processes in the closed loop control system. That is why the problem of mathematical model development for a controlled plant is an important one.

The mathematical model of a controlled plant can be developed by means of the following two ways [1,2]:

- theoretical way (development of the differential equations on the basis of mass and energy conservation laws);

- experimental way (development of the model on the basis of the registered transient processes for the known input disturbances).

The aim of this work is to develop a mathematical model of a controlled plant on the basis of the obtained experimental data and to implement the developed model in a programmable logic controller (PLC). A thermal object (i.e. electric oven) was chosen to be a controlled plant.

\section{Experimental study}

The experimental facility (see Fig. 1) consisted of a laboratory electric oven (SUOL-0,15.2/12M), air blower (VK-2) for blowing the air through the oven. A resistance thermometer (Pt100 of Techprylad Company) was installed inside the oven and connected (according to a three-wire diagram) to a programmable logic controller MIK-51H of

\footnotetext{
${ }^{*}$ Corresponding author. Email address: romanfedoryshyn@yahoo.com
} 
Microl company. The output signal of the thermometer was recorded by means of a personal computer with application of specialized software for data logging (MIK-registrator 1.1.14). A variable autotransformer (PHO-2502) was used to change the electric power at the input of the oven. The secondary connection of the transformer was rotated by means of an electric actuator with a position meter (KDU-1). A position indicator (DUP-K) was used for defining the position of the electric actuator.

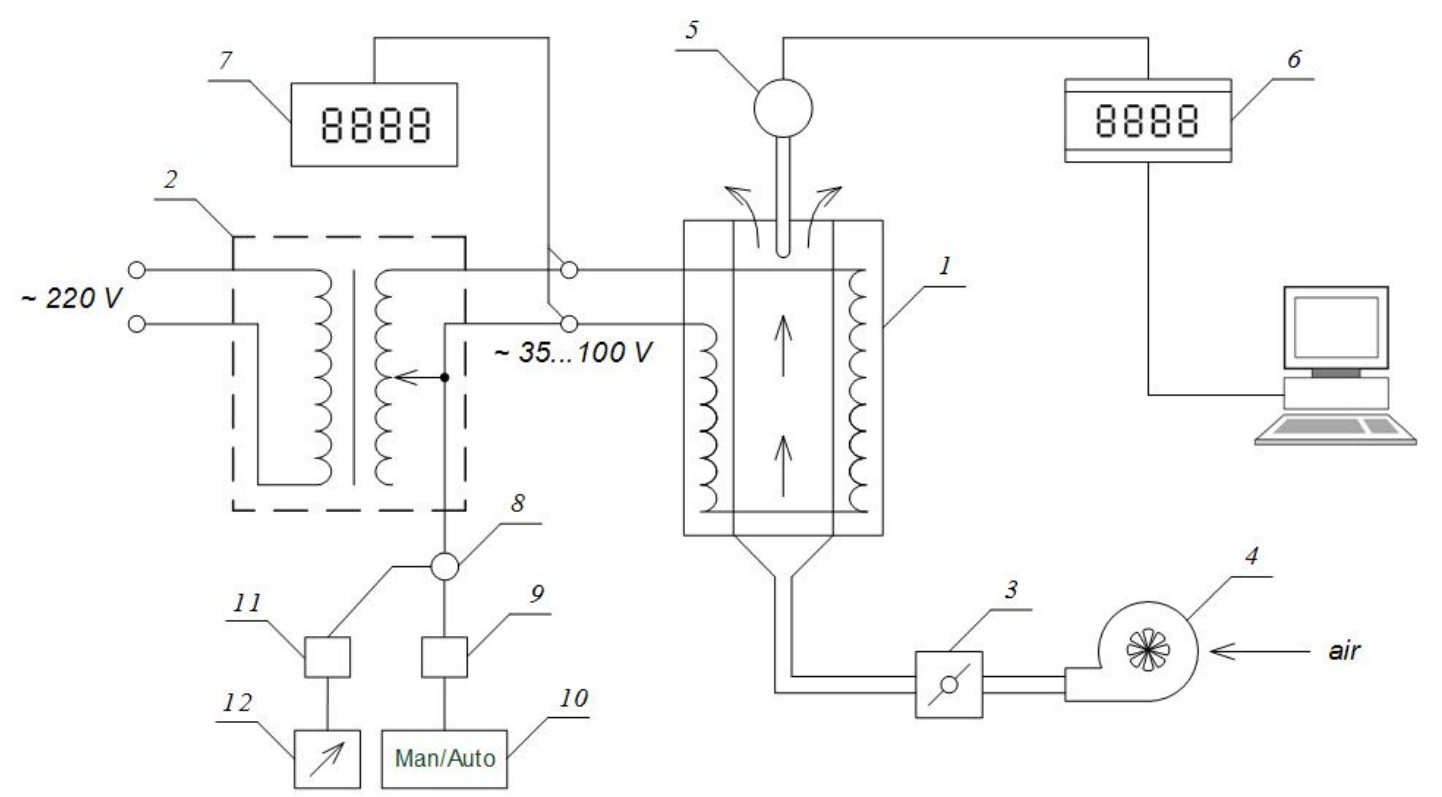

Fig. 1. Experimental facility diagram: 1 - electric oven; 2 - variable autotransformer (VATR); 3 - butterfly valve; 4 - air blower with an electric motor; 5 - resistance thermometer; 6 - programmable logic controller; 7 - voltmeter; 8 - electric actuator;

9 - amplifier; 10 - manual control station; 11 - actuator position meter; 12 - actuator position indicator.

There are two input variables and one output variable in the controlled plant under investigation. The output variable is the temperature $(\theta)$ measured by means of the resistance thermometer. One of the input variables is the position of the secondary connection of the variable autotransformer $\left(\mu_{V A T R}\right)$ being applied for changing the electric power at the input of the electric oven. This variable served as a controlling action for the plant. Another input variable is the position of the butterfly valve on the line of air input to the oven $\left(\mu_{\text {valve }}\right)$ for changing the air flow rate. This variable served as a disturbance for the controlled plant. The diagram of the controlled plant variables relations is presented in Fig. 2.

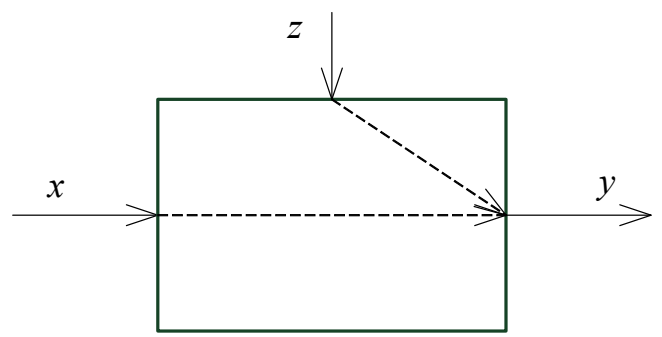

Fig.2. Diagram of the controlled plant variables relations: $x$ - first input variable ( $\mu_{V A T R}$, controlling action), $z$ - second input variable ( $\mu_{\text {valve }}$, disturbance), $y$ - output variable $(\theta)$.

Fifteen step response curves were registered during the experimental investigation. Thirteen of them were registered for the controlling action channel (by changing the position of VATR secondary connection). Two of the step response curves were registered for the disturbance channel (by changing the butterfly valve position).

Ten step response curves for the controlling action channel were registered during the first experiment. The position of VATR secondary connection was being changed in the range from $5 \%$ to $100 \%$ with the step of $20 \%$ through the upward and downward change in the position. The position of VATR secondary connection $\left(\mu_{\text {VATR }}\right)$ and 
its output voltage $(U)$ were registered for each equilibrium state of the plant. The registered points of the transient processes were transferred to MATLAB software where the curves of the transient processes were built (see Fig. 3).

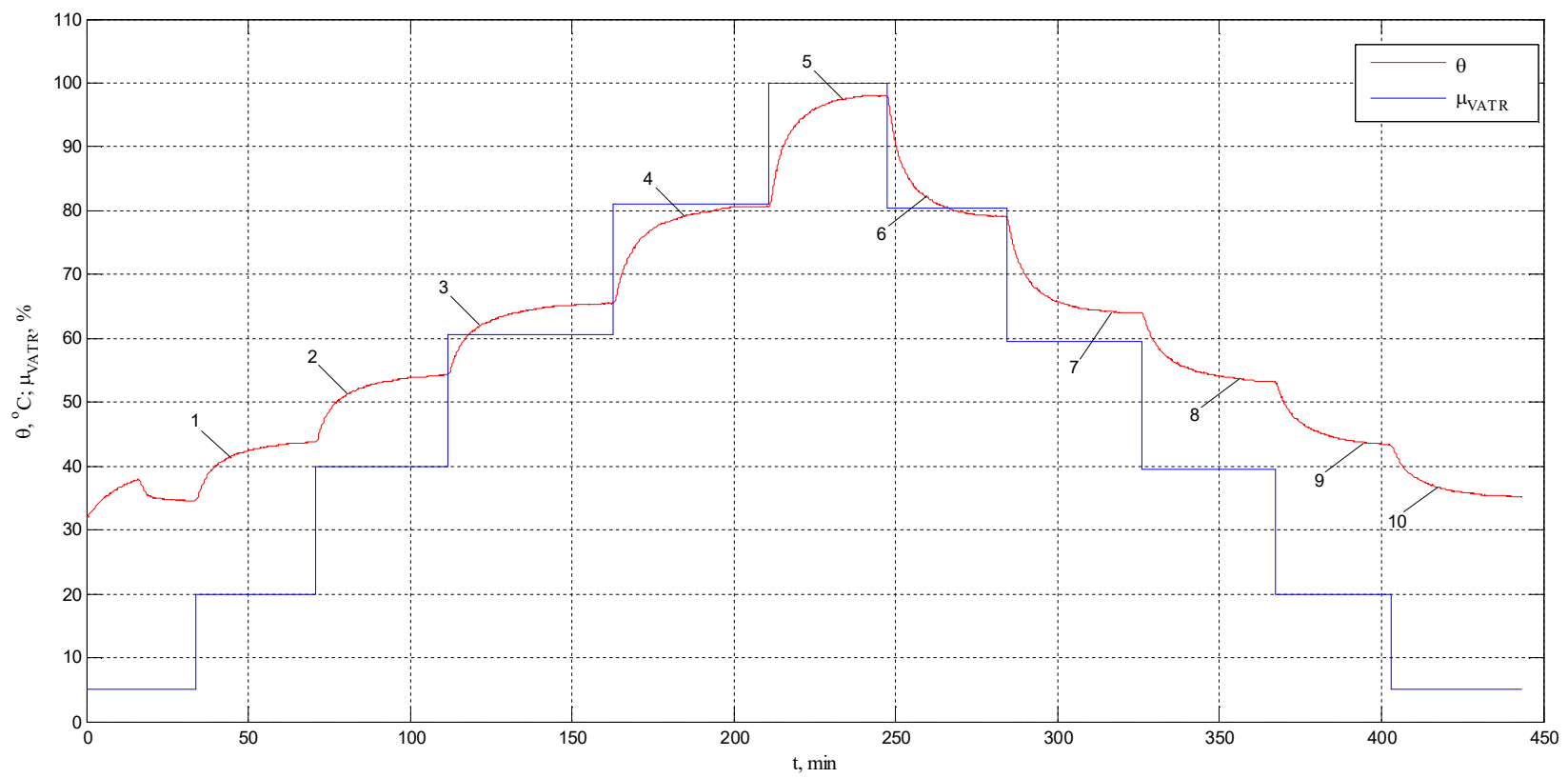

Fig.3. Step response curves for the controlling action channel (first experiment).

Five step response curves were registered during the second experiment. Three of them were registered for the controlling action channel (curves 1, 2, 3 in Fig. 4). And two of the step response curves were registered for the disturbance channel (curves 4 and 5 in Fig. 4).

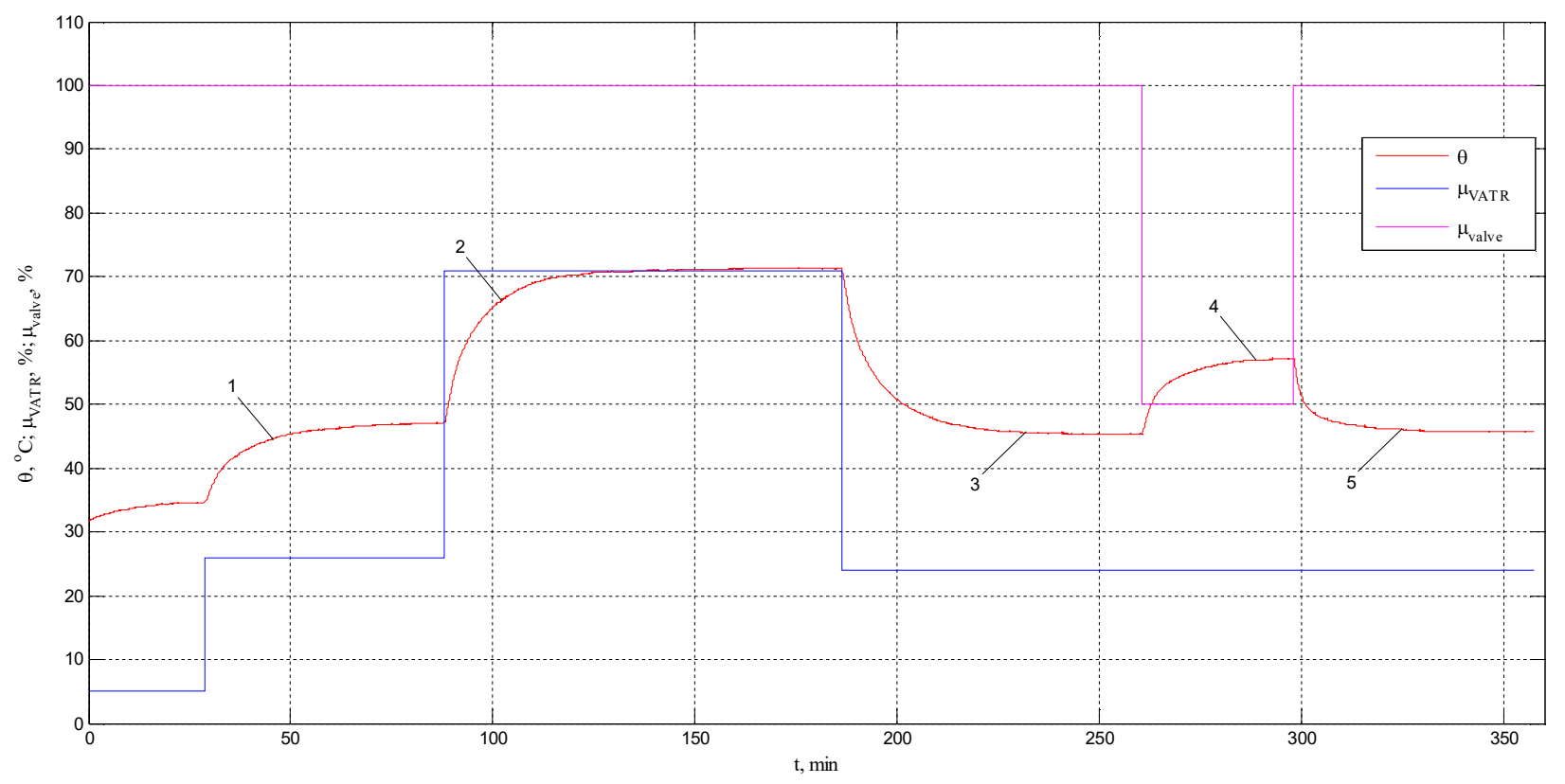

Fig.4. Step response curves for the controlling action channel and for the disturbance channel (second experiment).

It can be seen from the obtained experimental data that increase in the position of the VATR secondary connection leads to electric oven temperature raising (heating) and vice versa decrease in $\mu_{\text {VATR }}$ leads to cooling of the oven. By changing the position of the butterfly valve in the direction of closing the electric oven temperature becomes higher (see curve 4 in Fig. 4) and opening of the valve leads to cooling of the oven (curve 5 in Fig. 4). 


\section{Development of the mathematical model}

The obtained experimental data are the basis for development of the controlled plant mathematical model. The model consists of the following two parts: static model and dynamical model. The static model was developed in the form of static characteristics equations for the controlling action channel and for the disturbance channel. The dynamical model was developed in the form of transfer functions and differential equations for the controlling action channel and for the disturbance channel.

\subsection{Static model of the controlled plant}

The static characteristics equation describes the dependence of the output variable of the controlled plant on the input variable in the equilibrium state [3]. The static characteristics equations for the controlled plant under investigation were developed by means of approximating the experimental points of the controlled plant output variable in equilibrium states by linear equations. For this purpose polyfit function of MATLAB software was applied [4]. This function provides polynomial curve fitting.

As a result of approximation of the experimental points the following static characteristics equation was obtained for the controlling action channel:

$$
\theta=0.5446 \cdot \mu_{V A T R}+32.5359
$$

The following static characteristics equation was obtained for the disturbance channel:

$$
\theta=-0.2320 \cdot \mu_{\text {valve }}+68.7000
$$

The absolute and relative errors of the calculated values of static characteristics are presented in Table 1 and Table 2. The following notations are made in these tables: $\Delta$ is the absolute error of the calculated values with relation to the experimental points $\left(\theta_{\text {calc }}-\theta_{\text {experim }}\right) ; \delta$ is the relative error of the calculated values with relation to the experimental points $\left(\theta_{\text {calc }}-\theta_{\text {experim }}\right) / \theta_{\text {experim }} \cdot 100 \%$.

\begin{tabular}{|c|c|c|c|c|}
\hline$\mu_{\text {VATR }}, \%$ & $\theta_{\text {experim }},{ }^{\circ} \mathrm{C}$ & $\theta_{\text {calc }},{ }^{\circ} \mathrm{C}$ & $\Delta,{ }^{\circ} \mathrm{C}$ & $\delta, \%$ \\
\hline \multicolumn{5}{|c|}{ First experiment $\left(\mu_{\text {valve }}=100 \%\right)$} \\
\hline 5.0 & 34.60 & 35.26 & 0.66 & 1.91 \\
\hline 20.0 & 43.73 & 43.43 & -0.30 & -0.69 \\
\hline 40.0 & 54.26 & 54.32 & 0.06 & 0.11 \\
\hline 60.5 & 65.41 & 65.48 & 0.07 & 0.11 \\
\hline 81.0 & 80.62 & 76.65 & -3.97 & -4.92 \\
\hline 100.0 & 98.01 & 87.00 & -11.01 & -11.23 \\
\hline 80.5 & 79.06 & 76.38 & -2.68 & -3.39 \\
\hline 59.5 & 63.93 & 64.94 & 1.01 & 1.58 \\
\hline 39.5 & 53.16 & 54.05 & 0.89 & 1.67 \\
\hline 20.0 & 43.34 & 43.43 & 0.09 & 0.21 \\
\hline 5.0 & 35.15 & 35.26 & 0.11 & 0.31 \\
\hline \multicolumn{5}{|c|}{ Second experiment $\left(\mu_{\text {valve }}=100 \%\right)$} \\
\hline 5.0 & 34.6 & 35.26 & 0.66 & 1.91 \\
\hline 26.0 & 47.0 & 46.70 & -0.30 & -0.64 \\
\hline 71.0 & 71.2 & 71.20 & 0.00 & 0.00 \\
\hline 24.0 & 45.3 & 45.61 & 0.31 & 0.68 \\
\hline
\end{tabular}

Table 1. Comparison of calculated and experimental values of static characteristics points for the controlling action channel

Table 2. Comparison of calculated and experimental values of static characteristics points for the disturbance channel

\begin{tabular}{|c|c|c|c|c|}
\hline$\mu_{\text {valve }} \%$ & $\theta_{\text {experim }},{ }^{\circ} \mathrm{C}$ & $\theta_{\text {calc }},{ }^{\circ} \mathrm{C}$ & $\Delta,{ }^{\circ} \mathrm{C}$ & $\delta, \%$ \\
\hline \hline \multicolumn{5}{|c|}{ Second experiment $\left(\mu_{\text {VATR }}=24 \%\right)$} \\
\hline 100 & 45.3 & 45.5 & 0.2 & 0.44 \\
\hline 50 & 57.1 & 57.1 & 0.0 & 0.00 \\
\hline 100 & 45.7 & 45.5 & -0.2 & -0.44 \\
\hline
\end{tabular}


We can see from Table 1 that the maximum relative error of the calculated values of static characteristics for the controlling action channel is not more than $5 \%$ in the range of $\mu_{V A T R}$ from 5 to $80 \%$ at $\mu_{v a l v e}=100 \%$. The maximum relative error of the calculated values of static characteristics for the disturbance channel is not more than $0.5 \%$ in the range of $\mu_{\text {valve }}$ from 50 to $100 \%$ at $\mu_{\text {VATR }}=24 \%$.

\subsection{Dynamical model of the plant for the controlling action channel}

Development of the dynamical model of the plant for the controlling action channel was made on the basis of the following two experimental step response curves: heating curve (curve 2 in Fig. 4) and cooling curve (curve 3 in Fig. 4). These two curves were normalized (see Fig. 5).

The dynamics of the transient processes is influenced by the electric oven inertia and by the thermometer inertia. So the controlled plant includes two capacities and its behavior can be described by the second-order lag element.

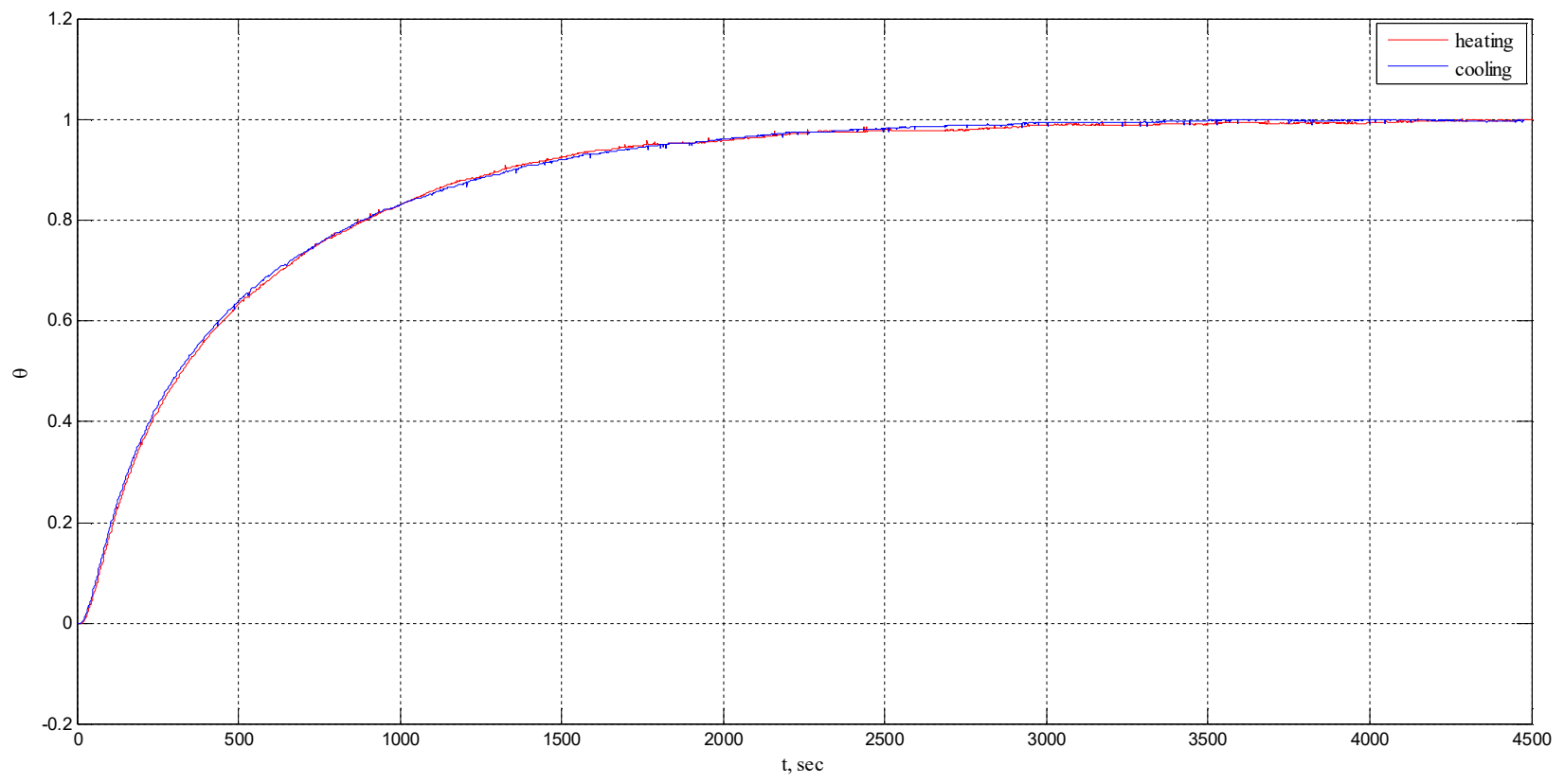

Fig.5. Normalized experimental step response curves for the controlling action channel.

We can see from Fig. 5 that the heating curve and the cooling one almost coincide. It means that for the controlling action channel the dynamics of the plant during heating and during cooling is the same. It also can be seen from Fig. 5 that there is an inflection point at the beginning of the curve. Since there are two capacities in the controlled plant (CP), the following structure of the transfer function for the controlling action channel was chosen:

$$
W_{C P}^{x}(s)=\frac{k_{x}}{T_{2 x}^{2} s^{2}+T_{1 x} s+1},
$$

where $k_{x}$ is the gain coefficient of the plant for the controlling action channel; $T_{1 x}, T_{2 x}$ are time constants for the controlling action channel; $s$ is Laplace operator.

An averaged experimental curve was built on the basis of the normalized heating and cooling curves. This averaged experimental curve was approximated by a theoretical one using the following three methods for defining the time constants $T_{1 x}$ and $T_{2 x}$ of transfer function (3): numerical, graphic-analytical and combined method.

The numerical method of defining the time constants consists in application of fminsearch function of MATLAB software [4]. Fminsearch finds the minimum of a multi-parameter goal function using the Nelder-Mead simplex method. In our case the goal function was the sum of squares of deviations of the theoretical curve from the experimental one. And the time constants $T_{1 x}$ and $T_{2 x}$ were the parameters defined by fminsearch. 
According to the graphic-analytical method an inflection point should be found on the experimental curve and a tangent line should be built through this point. The values of the time constants are calculated using the length of some segments and the area between the curve and the asymptote. The graphic-analytical method of defining the time constants on the basis of the step response curves is described in [5].

The results of time constants definition using various methods are presented in Table 3. There are also values of maximum reduced errors $\left(\delta_{\max }\right)$ of theoretical curve with relation to the experimental one for each method in the table.

Table 3. The results of time constants definition for the controlled plant transfer function (controlling action channel)

\begin{tabular}{|l|c|c|c|}
\hline \multicolumn{1}{|c|}{ Method of time constants definition } & $T_{1 x}, \mathrm{sec}$ & $T_{2 x}, \mathrm{sec}$ & $\delta_{\max } \%$ \\
\hline \hline Numerical & 524.770 & $3.2 \cdot 10^{-5}$ & 5 \\
\hline Graphic-analytical & 352.827 & 112.238 & 14 \\
\hline Combined & 524.77 & 112.238 & 7 \\
\hline
\end{tabular}

As we can see from Table 3 the smallest error is provided by the numerical method. The error is equal to $5 \%$. However, the time constant $T_{2 x}$ is approximately equal to zero for this method. It means that the dual-capacity plant is approximated by a first-order lag element which is not an adequate description of a dual-capacity plant behavior.

The graphic-analytical method provides a good description of a dual-capacity plant behavior because the time constants $T_{1 x}$ and $T_{2 x}$ are commensurable here and there is an inflection point on the theoretical curve at the same time moment as on the experimental curve. However, the error of this method is big. It is equal to $14 \%$.

It is proposed to apply the combined method for the time constants definition. According to this method the time constant $T_{1 x}$ is taken from the numerical method and $T_{2 x}$ from the graphic-analytical one. The combined method provides an adequate description of the dual-capacity plant behavior with an acceptable error. The value of the error is equal to $7 \%$ for the combined method.

The transfer function of a second-order lag element (3) can be presented in the form of a product of two firstorder lag elements:

$$
W_{C P}^{x}(s)=\frac{k_{x}}{\left(a_{x} s+1\right)} \cdot \frac{1}{\left(b_{x} s+1\right)} .
$$

The time constants $a_{x}$ and $b_{x}$ here for the combined method of time constants definition take the following values: $a_{x}=499.55 \mathrm{sec}, b_{x}=25.22 \mathrm{sec}$. The gain coefficient on the basis of the static characteristics equation for the controlling action channel takes the following value $k_{x}=0.5446{ }^{\circ} \mathrm{C} / \%$.

\subsection{Dynamical model of the plant for the disturbance channel}

Development of the dynamical model of the plant for the disturbance channel was made on the basis of the following two experimental step response curves: heating curve (curve 4 in Fig. 4) and cooling curve (curve 5 in Fig. 4). The disturbance was introduced by means of changing the air flow rate through the oven, i.e. by changing the position of the butterfly valve. The valve was closed by $50 \%$ and the temperature started to rise (curve 4 in Fig. 4). After coming to the equilibrium state the valve was opened back to $100 \%$ and the temperature started to drop (curve 5 in Fig. 4). These two curves were normalized (see Fig. 6).

It can be seen from Fig. 6 that the dynamics during heating is different from that during cooling. The following structure of the transfer function for the disturbance channel (second-order lag element) was chosen:

$$
W_{C P}^{z}(s)=\frac{k_{z}}{T_{2 z}^{2} s^{2}+T_{1 z} s+1}
$$

where $k_{z}$ is the gain coefficient of the plant for the disturbance channel; $T_{1 z}, T_{2 z}$ are time constants for the disturbance channel. 


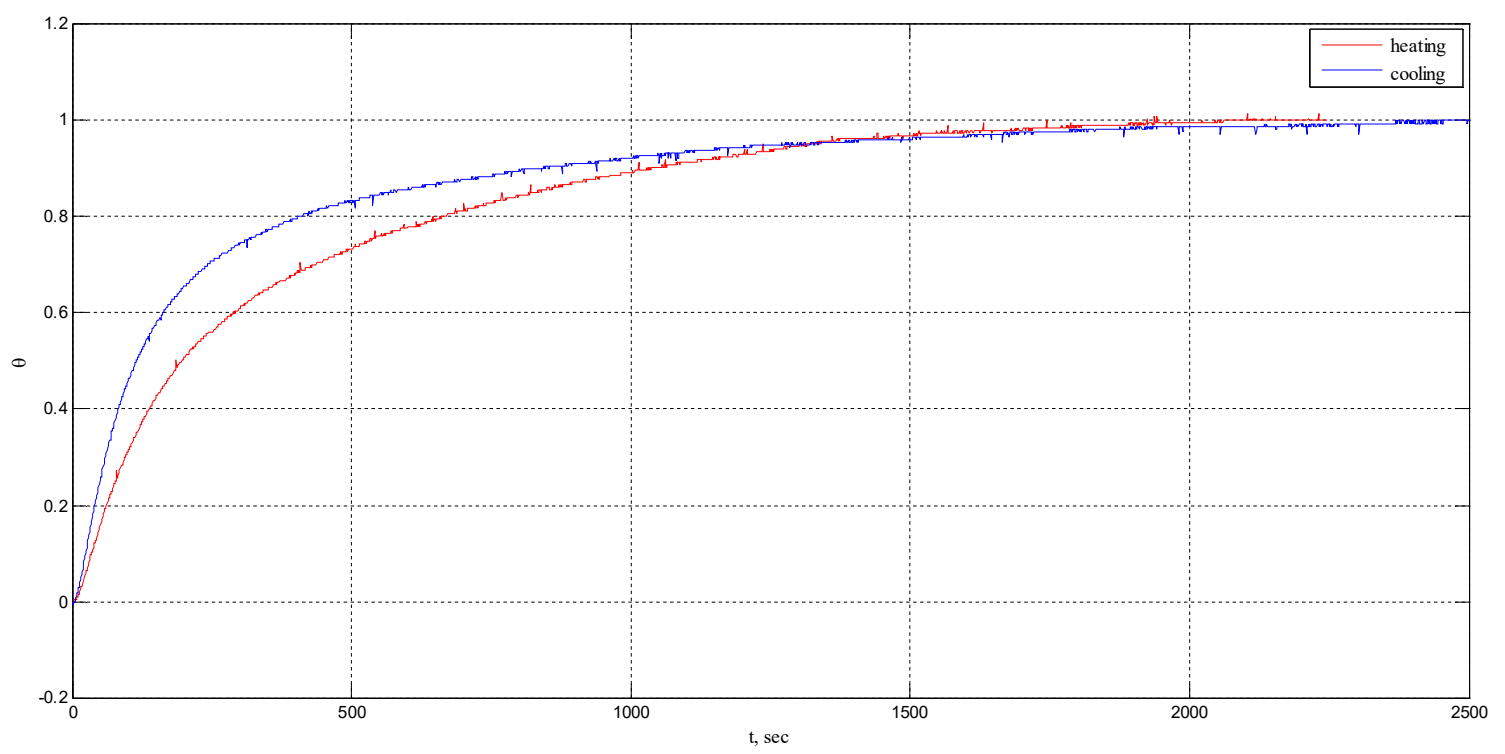

Fig.6. Normalized experimental step response curves for the disturbance channel.

An averaged experimental curve was built on the basis of the normalized heating and cooling curves presented in Fig. 6. This averaged experimental curve was approximated by a theoretical one using the three methods for defining the time constants $T_{1 z}$ and $T_{2 z}$ of transfer function (5) in a similar way like it was done for the controlling action channel (numerical, graphic-analytical and combined method). However, none of the methods provided an acceptable accuracy of the theoretical curve. The errors were equal to $11 \%$ for the numerical method, $18 \%$ for the graphicanalytical method and $12 \%$ for the combined method. Since the values of the errors were big, it was decided to change the structure of the model. The mathematical model of the controlled plant for the disturbance channel was developed in two stages.

At the first stage a correction element was introduced into the transfer function of the controlled plant for the disturbance channel. This correction element is a real differentiation element with a transport delay. A modified structure of the model can be presented by the following transfer function:

$$
W_{C P}^{z}(s)=\frac{k_{z}}{\left(a_{z} s+1\right)} \cdot \frac{1}{\left(b_{z} s+1\right)}-\frac{k_{k} a_{k} s}{\left(a_{k} s+1\right)} \cdot \frac{\mathrm{e}^{-\tau \cdot s}}{\left(b_{k} s+1\right)}
$$

where $a_{z}, b_{z}$ are time constants for the disturbance channel; $k_{k}$ is the gain coefficient of the correction element; $a_{k}, b_{k}$ are time constants of the correction element; $\tau$ is transport delay of the correction element.

This type of the correction element was defined in the following way (see Fig. 7): the blue curve is the normalized experimental step response curve (cooling curve); the green curve is the theoretical curve on the basis of the first term of transfer function (6) with time constants obtained by means of the graphic-analytical method. By subtracting the blue curve from the green one the red curve was obtained. The red curve was approximated by the cyan curve using the transfer function of a real differentiation element with a transport delay which corresponds to the introduced correction element (second term of transfer function (6)). By subtracting the cyan curve from the green one the violet curve was obtained. The violet curve corresponds to the theoretical step response curve obtained by means of transfer function (6).

At the second stage the first multiplier of the first term of transfer function (6) was replaced by a nonlinear differential equation (in order to provide different dynamics during heating and during cooling):

$$
\frac{k_{z}}{\left(a_{z} s+1\right)} \longrightarrow a_{z} \cdot \frac{d y_{\text {int } 1}}{d t}+\left(y_{\text {int } 1}\right)^{n}=c \cdot k_{z} \cdot z,
$$

where $y_{\text {int } 1}$ is the intermediate signal between the two firs-order lag elements of the first term of transfer function (6); $n$ is an index providing the nonlinearity of the differential equation; $c$ is a correcting factor. 


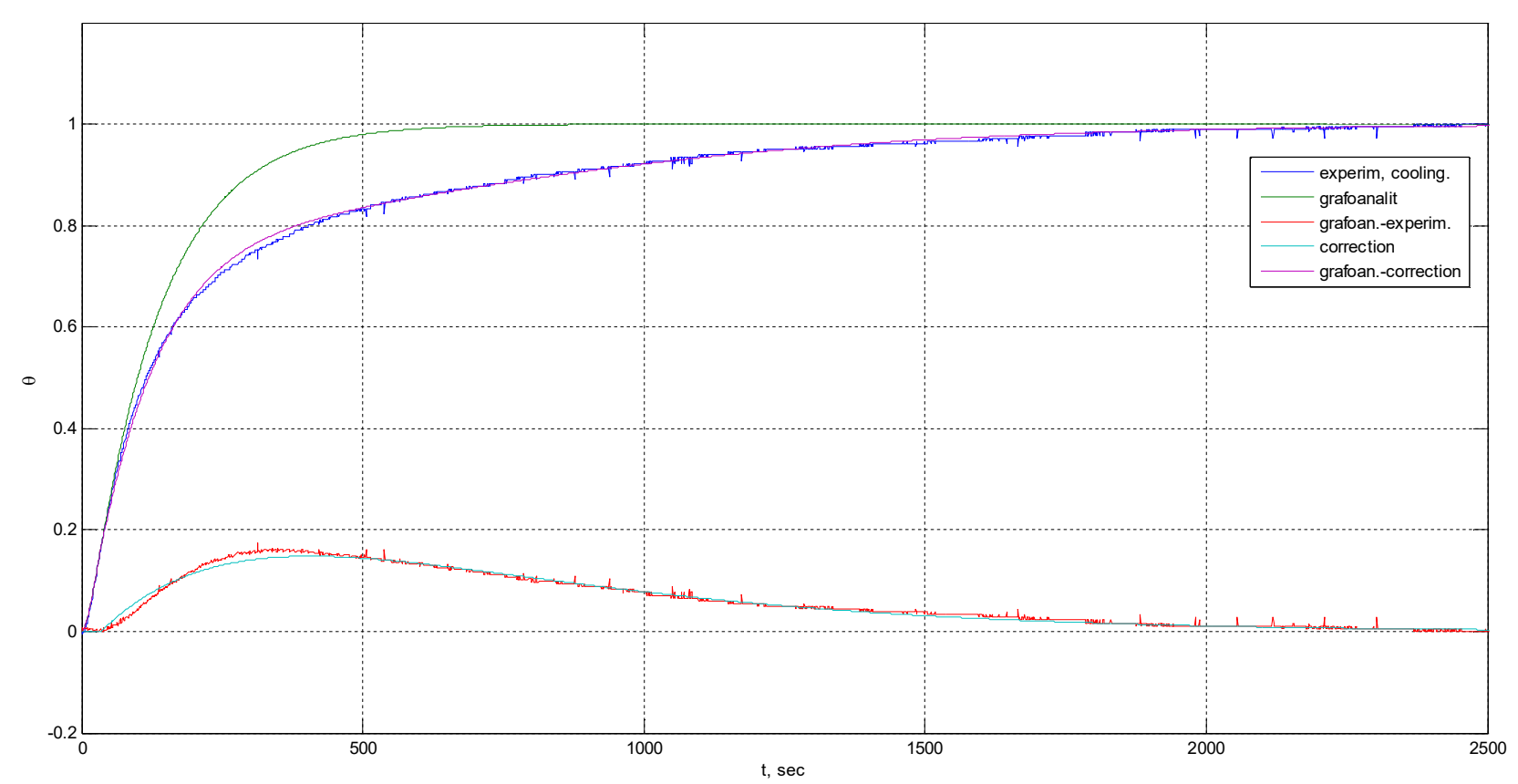

Fig.7. Experimental and theoretical step response curves.

The obtained dynamical model of the controlled plant for the disturbance channel can be presented by means of the following system of differential equations:

$$
\left\{\begin{array}{l}
a_{z} \cdot \frac{d y_{\text {int } 1}}{d t}+\left(y_{\text {int } 1}\right)^{n}=c \cdot k_{z} \cdot z \\
b_{z} \cdot \frac{d y_{z}}{d t}+y_{z}=y_{\text {int } 1} \\
a_{k} \cdot \frac{d y_{\text {int } 2}}{d t}+y_{\text {int } 2}=k_{k} \cdot a_{k} \cdot \frac{d z}{d t} \\
b_{k} \cdot \frac{d y_{k}}{d t}+y_{k}=y_{\text {int } 2} \\
y(t)=y_{z}(t)-y_{k}(t-\tau)
\end{array}\right.
$$

where $y_{\text {int } 2}$ is the intermediate signal between the two multipliers of the second term of transfer function (6).

The product of the two first-order lag elements of the first term of transfer function (6) with the introduced nonlinearity is described by the first two equations of system (8). The product of the two transfer functions of the correction element (second term of transfer function (6)) without taking into account the transport delay is described by the third and fourth equations of system (8). The difference of the two terms of transfer function (6) and the transport delay of the correction element is described by the fifth equation of system (8). The numerical values of the obtained model parameters are as follows:

$$
\begin{array}{ll}
a_{z}=90.46 \mathrm{sec} ; & \tau=35 \mathrm{c} ; \\
b_{z}=10.91 \mathrm{sec} ; & a_{k}=b_{k}=282.66 \mathrm{sec} ; \\
k_{z}=-0.2320^{\circ} \mathrm{C} / \% ; & n=0.8494 ; \\
k_{k}=-0.1339{ }^{\circ} \mathrm{C} / \% ; & c=0.6913 .
\end{array}
$$

If $n$ and $c$ in the first equation of system (8) were equal to unity, this system of differential equations would become linear and it would completely correspond to the transfer function (6).

Based on the obtained model the step response curves were simulated and compared to the experimental ones. The maximum reduced error of the theoretical heating curve is $9 \%$. For cooling curve this error is $6 \%$. 


\section{Implementation of the developed model by means of a PLC}

The developed mathematical model of the controlled plant was implemented (programmed) in MIK-51H PLC of MICROL Company [6]. For this purpose Alfa 2.0 software [7] was applied. The trends of the transient processes were registered by means of MIK-registrator 1.1.14 software [8]. The structural diagram of the controlled plant model implemented in the PLC is presented in Fig. 8. This diagram consists of the following two parts: lower part (it is the model of the plant for the controlling action channel); upper part (it is the model of the plant for the disturbance channel). Transfer function (4) is implemented in the lower part of this diagram. The system of differential equations (8) is implemented in the upper part of the diagram.

The first-order lag elements are presented by the integrators with negative feedbacks in the diagram of the controlled plant model (Fig. 8). This schematic solution was applied in order to switch the model into the initial condition quickly by zeroing the integrators. Such a solution provides significant saving of time during the experimental study of the model implemented in the PLC (e.g. when the experiment needs to be restarted with modified parameters of the model or program in PLC).

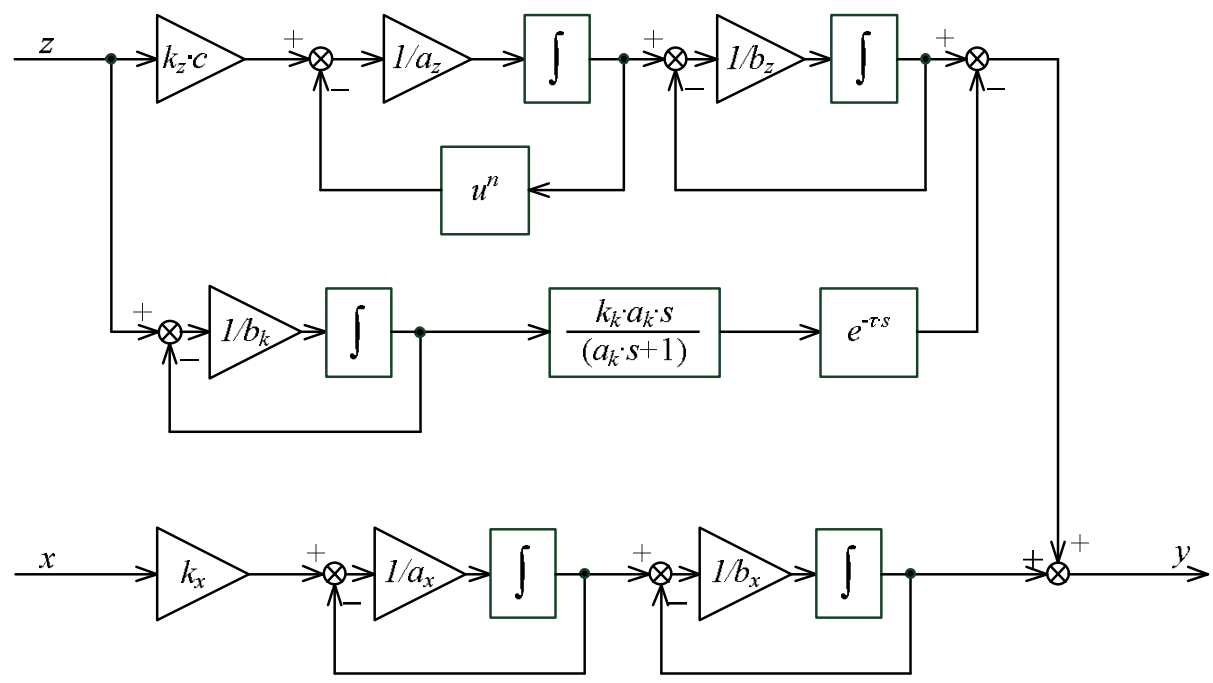

Fig.8. Structural diagram of the controlled plant model implemented in the PLC.

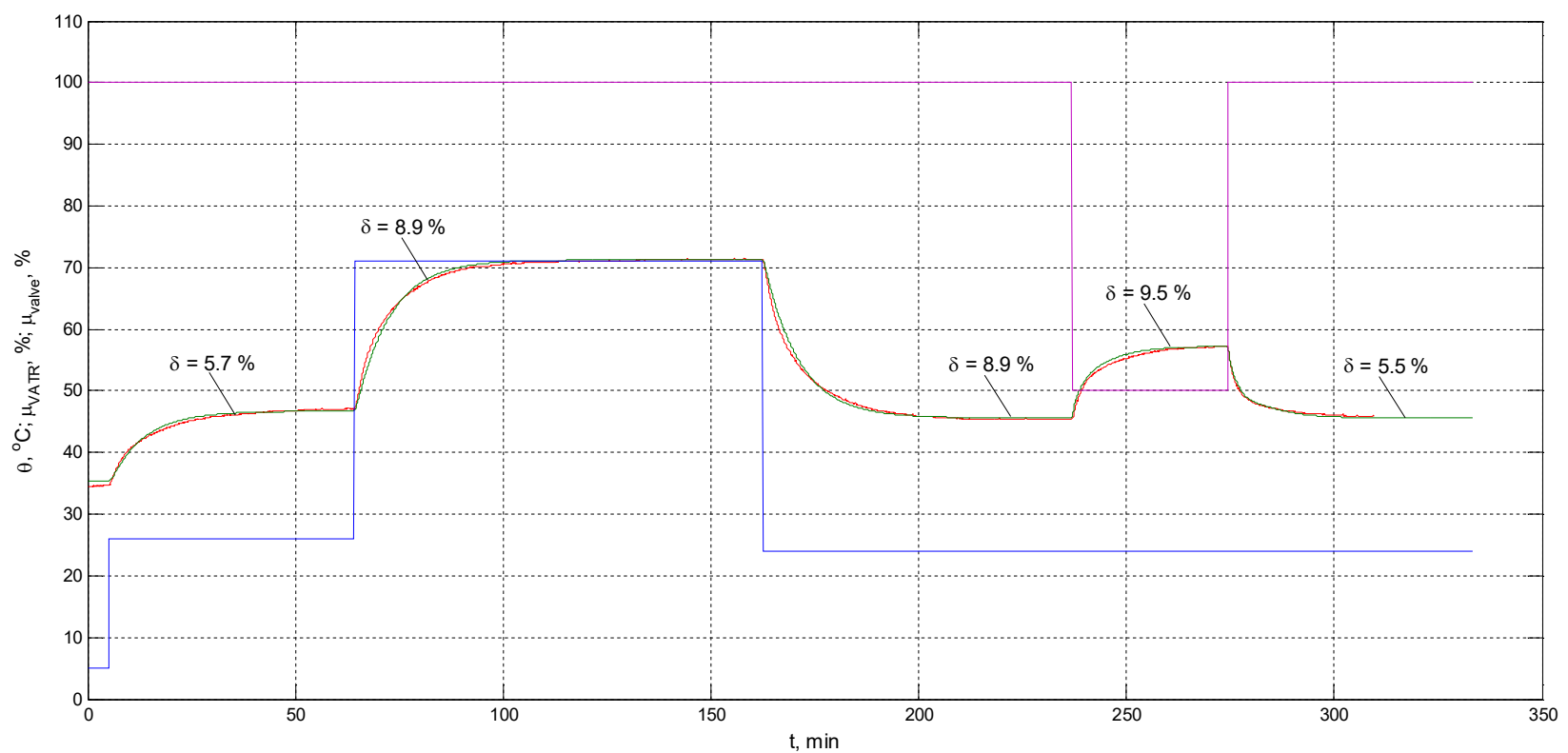

Fig.9. Comparison of the experimental transient processes: red curve - output variable, $\theta$ (electric oven); green curve - output variable, $\theta$ (PLC); blue curve - input variable, $\mu_{V A T R}$ (controlling action); violet curve - input variable, $\mu_{\text {valve }}$ (disturbance). 
The experimental transient processes registered in the actual controlled plant (electric oven) were compared to the experimental transient processes registered in the PLC where the model of the plant was implemented. The curves of these transient processes are presented in Fig. 9.

It can be seen from Fig. 9 that the transient processes registered in the PLC (green curve) almost coincide with the experimental transient processes registered in the actual controlled plant (red curve). The maximum reduced error for each curve registered in the PLC correspond to the total error introduced by the dynamical model and by the static model. The values of the errors do not exceed $10 \%$.

\title{
5. Conclusion
}

Experimental investigation of a controlled plant (electric oven) was made. Step response curves for the controlling action channel and for the disturbance channel were registered. Mathematical model of the controlled plant was developed on the basis of the obtained experimental data. The adequacy of the model was proved by comparing the theoretical step response curves with the experimental ones. The developed model was implemented in a PLC.

The mathematical model of the controlled plant can be applied for designing the structure of an automatic controller, for calculating the numerical values of the controller tuning parameters as well as for studying the transient processes in the closed loop control system.

\section{References}

[1] Stentsel Y. I. Mathematical Modeling of Technological Control Objects: textbook. - Kyiv: ISDO, 1993. - 328 p. (in Ukrainian)

[2] Polotskyi L. M., Lapshenkov G. I. Automation of Chemical Production. Theory, Calculation and Design of Automation Systems. - Moscow: Chemistry, 1982. - 296 p. (in Russian)

[3] Pistun Y. P., Stasiuk I. D. Fundamentals of Automatics and Automation. Textbook. Lviv. Publishing House of Lviv Polytechnic, 2014. - 336 p. (in Ukrainian)

[4] Anufriev I. E. MatLab 5.3/6.x Manual for Self-Tuition - SPb.: BKhV-Peterburg, 2002 - 736 p. (in Russian)

[5] Plaskowski A. Experimental Study of Dynamical Properties of Controlled Plants. Science and Engineering Publishing House, Warsaw, 1965, 177 p. (in Polish)

[6] MIK-51H Microprocessor Controller. Operations Manual. PRMK.421457.006RE1. Ivano-Frankivsk, 2015 (in Russian)

[7] Software. ALFA, Editor of FBD-programs for Controllers of MIK-51 and MIK-52 Series. Version 2.0.0.705. Operations Manual. PRMK.426000.003RE. Ivano-Frankivsk, 2015 (in Russian)

[8] “MIK-registrator” Software. Version 1.1.14. Operations Manual PRMK.426000.002RE. Ivano-Frankivsk, 2010 (in Russian)

\section{Ідентифікація об'єкта регулювання та побудова його моделі за допомогою ПЛК}

\author{
Роман Федоришин, Святослав Кльось, Володимир Савицький, Олег Масняк \\ Національний університет «Львівська політехніка», вул. Степана Бандери, 12, Львів, 79013, Україна
}

\section{Анотація}

Представлено результати експериментального та теоретичного дослідження динамічних та статичних характеристик теплового об'єкту (електричної печі) як об'єкта керування із застосуванням сучасних мікропроцесорних засобів. Експериментальне дослідження об'єкта було виконане шляхом нанесення стрибкоподібних збурень каналом регулюючої дії та каналом збурення. У результаті досліджень було зареєстровано п’ятнадцять кривих розгону, які стали основою для побудови математичної модель об'єкта у вигляді рівнянь статичних характеристик, функцій передачі та диференціальних рівнянь. Вибрано структуру моделі, розраховано числові значення ії параметрів та здійснено перевірку адекватності цієї моделі. Відносна похибка розрахунку точок статичної характеристики не перевищує 5\%. Максимальна зведена похибка змодельованої кривої розгону для каналу регулювання відносно експериментальної кривої становить 7 \% для запропонованого комбінованого способу визначення сталих часу. Розроблена модель об'єкта була реалізована у програмовано-логічному контролері шляхом програмування, що дає можливість досліджувати роботу замкненої системи автоматичного регулювання із різними законами регулювання.

Ключові слова: об’єкт регулювання; крива розгону; перехідний процес; математична модель; електрична піч. 